\title{
1972 BEST YEAR YET FOR SASKATOON BLUEBIRD HOUSE TRAIL
}

\section{BY DAVID V. HOUSTON*}

This, the. Saskatoon Junior's part of the trail, has remained fairly steady at 410 birdhouses of which 216 are in our main study area. As will be seen in the table, we had 25 pairs of Mountain Bluebirds, up from 12 pairs last year: they seem to double in numbers each year. We had, unfortunately, 48 pairs of House Sparrows; they have also made a great jump lately, perhaps because they prefer older house; last year we had only 17 pairs. And, with the four species on the trail. we had attained a remarkable $98.7 \%$ occupancy rate for our houses.

Another 21 houses were added after nesting this fall to join up with Mr. Jake Kargut in Langham. This is only his second year and Mr. Kargut now has 200 hirdhouses in use, extending as far as Borden. This year he had 45 pairs of Mountain Bluebirds, 101 pairs of Tree Swallows, 9 pairs of House Wrens, and 8 pairs of House Sparrows in his boxes.

$\begin{array}{lcccc}\text { Year } & 1969 & 1970 & 1971 & 1972 \\ \text { Total houses } & 207 & (368) & (412) & (410) \\ \text { In study area } & (115) & 182 & 208 & 216 \\ \text { Tree Swallows } & 128 & 130 & 172 & 161 \\ \text { Mountain Bluebirds } & 3 & 8 & 12 & 25 \\ \text { House Sparrows } & 11 & 11 & 17 & 48 \\ \text { House Wrens } & 2 & 0 & 0 & 2 \\ \text { Total occupied } & 134 & 145^{*} & 191 * * & 213 * * \\ \text { Intact, empty } & 11 & 15 & 12 & 2 \\ \text { Damaged, empty } & 11 & 15 & 12 & \\ \text { Damaged empty } & 62 & 22 & 5 & 1 \\ \text { Occupancy rate } & 65 \% & 80 \% & 91 \% & 98.7 \% \\ \text { Tree Swallows banded } & 10 & 10 & & \\ \text { Tree Swallows banded } & 193 & 324 & 662 & 664 \\ \text { Mountain Bluebirds banded } & 10 & 21 & 53 & 157\end{array}$

Note: Statistics are taken from the underlined numbers, not from the numbers in parentheses, ince regular checks are now restricted to houses within 60 miles of Saskatoon.

"By 149 pairs in 1970. In four cases, a house was used successively by two species: two had Tree Swallows and Mountain Bluebirds; 2 had Tree Swallows and House Sparrows.

**B 201 pairs in 1971. Ten houses were used by two species: five had Tree Swallows and Mountain Bluebirds; five had Tree Swallows and House Sparrows.

** By 234 pairs in 1972. Twenty-one houses were used by two species: 12 had Tree Swallows and House Sparrows; 7 had Tree Swallows and Mountain Bluebirds; I had Mountain Bluebirds and House Sparrows; and 1 had Mountain Bluebirds and House Wrens.

863 University Drive, Saskatoon.

\section{NEST RECORDS}

Anyone wishing to participate in the Prairie Nest records scheme in 1973 may obtain information and cards from:

H. W. R. Copland,

Manitoba Museum of Man and

lave a pen or pencil handy? Why not

ill out the questionnaire at the front of

Nature,

190 Rupert Ave.,

Winnipeg Manitoba R3B 0N2. 